\title{
Effectiveness of Sugar Industry Organic Wastes in Reducing Soil Compatibility in Soils of Three Ethiopian Sugar Estates
}

\author{
Tesfaye Wakgari \\ College of Natural Resource Management and Veterinary Science, Ambo University, Ambo, Ethiopia \\ Email address: \\ wagarit06@gmail.com
}

\section{To cite this article:}

Tesfaye Wakgari. Effectiveness of Sugar Industry Organic Wastes in Reducing Soil Compatibility in Soils of Three Ethiopian Sugar Estates. International Journal of Energy and Environmental Science. Vol. 6, No. 4, 2021, pp. 86-95. doi: 10.11648/j.ijees.20210604.13

Received: July 30, 2021; Accepted: August 17, 2021; Published: August 27, 2021

\begin{abstract}
Incorporation of sugarcane industry by-products into soil can reduce the susceptibility of soils to compaction. However, the significance of incorporated filter cake and filter cake compost at different soil water contents at the time of compaction using proctor test load is not well documented. In this context, study was conducted at three Ethiopian sugar Estates in 2017 to examine the effect of filter cake and filter cake compost incorporation to three soils different in clay content on soil maximum dry density, total porosity at MDD, critical moisture content under laboratory conditions. Sugarcane residues were added to soils at rates of $0,7.75 \mathrm{~g}$ of residues per $\mathrm{kg}$ of soils. The results of the study showed that the maximum dry bulk density with no sugarcane residue added was achieved at $15.94 \%$ for light, $25 \%$ for medium and $28.6 \%$ for heavy clay. Filter cake incorporated at the rate of $30 \mathrm{t} \mathrm{ha}^{-1}$ reduced the soil compactibility induced by proctor test load at water content of $0.7 \mathrm{PL}$ for light clay soils, 0.97 PL for medium clay and at water content of $0.98 \mathrm{PL}$ for the heavy clay soils. In all three soil types at 0 $\mathrm{t} \mathrm{ha}^{-1}$ and $30 \mathrm{t} \mathrm{ha}^{-1}$ residue application levels, the total porosity attained a minimum value at critical moisture content and critical moisture content for the maximum dry density increased as the clay content increased. Filter cake and filter cake compost reduced the maximum dry density of heavy clay soil by 4 and $27.6 \%$, respectively, as compared to the control. Nevertheless, this residues increased total porosity at critical moisture content, respectively, by 2.44 and $46.9 \%$ over the control for heavy clay soils. Therefore, it can be concluded that sugarcane residue was most effective in reducing soil compactibility at moisture content less than PL compared to water content higher than PL. Moreover, filter cake compost was more effective in reducing soil compactibility than filter cake. Finally, the study recommended that the heavy machineries operation during sugarcane seedbed preparation and harvesting; shall be made when soil moisture is below $0.60,0.9$ and 0.91 PL, respectively, for light, medium and heavy clay soils and after treating the soil with either filter cake or filter cake compost tentatively. Nevertheless, in order to give conclusive recommendation further research studies are needed for more soil clay levels for the case of filter cake compost and more rates for both sugarcane residues.
\end{abstract}

Keywords: Soil Compactbility, Proctor Test, Sugarcane Residues, Soil Types

\section{Introduction}

Compaction is a worldwide problem in modern agriculture associated with overuse of heavy machinery and intensification of cropping systems [1]. Likewise, in Ethiopia sugarcane is mechanized crop in which soil compaction may occur during heavy machine operations for cultivation. Several researchers suggested that the most serious factor associated with soil compaction under sugarcane is loss of soil organic matter due to intensive tillage operation [2]. Soil organic carbon (SOC) influences the ability of soil to resist compactive loads. Soils with organic matter levels above $3.4 \%$ (threshold value) are less vulnerable to soil compaction [3]. The decline in the level of organic matter even below the threshold value may aggravate soil compaction. Hugar and Soraganvi [4] reported that soil compactibility caused by heavy machinery can be reduced by incorporating organic residues.

The use of heavy machinery in fine textured soils with low organic matter has led to the concern that subsoil compaction 
may occur and result in declining long term productivity [5]. The fine textured soils are dominant in the three main white sugar producing factories in Ethiopia. According to report by Ambachew and Abiy [6], 95\% of Wonji-Shoa, 98\% of Metahara and $97 \%$ of Finchaa Estate total sampled sites have more than $30 \%$ clay content. Most of the high clay soils at Wonji-Shoa and Metahara Estates have expansive clay to a depth of $60 \mathrm{~cm}$ [7]. Of the most common clay minerals it is montmorillonite that is dominantly present in most of the estate soils [8]. Potentially expansive soils can typically be recognized in the laboratory by plastic properties [9]. These properties can be measured in the laboratory directly by testing Atterberg's limits and proctor tests [10]. The modified proctor test is used in order to increase the compaction effort applied during the test and to better simulate heavy tractors during field operations.

The results of different studies e.g. Mari and changying [11] andMari and changying [12] indicated that the degree to which soils will compact when a force is applied by heavy machine is primarily dependent on the amount of water present. Furthermore, for given water content, the compactibility of soils depends on clay and organic matter contents $[13,14]$. These relationships affect the moisture content at which maximum bulk density will be achieved for soils into which sugarcane residues are incorporated and can be used for determining soil compaction reducing effects of the by-products $[15,16]$.

Studies have indicated that crop residues such as wheat straw and corn residues decrease soil compactibility [17]. However, the influence of sugarcane residues such as filter cake and filter cake compost on soil compactibility is not well documented. Particularly, information is scarce on interactions between filter cake, soil water content and dry bulk density at the time of compaction and the compressing energy of proctor test load in Ethiopian sugarcane plantations. This information can be used to plan waste management by applying the byproducts of the sugar factories for reducing soil compactibility of the estates and could help to schedule farm trafficking and cultivation operations at the proper moisture content. Consequently, there is a need to test the different practices available to reduce soil compactibility during field operations in Ethiopian Sugarcane Estates.

Therefore, it is necessary to determine the conditions in which filter cake and filter cake compost will have the optimum effect on soil compactibility, and the extent to which it can reduce soil compactibility. Based on all these aspects, this study was initiated with the objective of evaluating the changes in soil dry bulk density following filter cake and filter cake compost addition using modified proctor compaction load.

\section{Materials and Methods}

\subsection{Descriptions of the Study Areas}

The study was conducted in 2017 at three commercial sugarcane production fields of Wonji-Shoa, Metahara and Finchaa Sugar Estates. The study areas, Wonji-Shoa, Metahara and Finchaa Sugar Estates, were located at a distance of 107, 200 and $374 \mathrm{~km}$, respectively, from Addis Ababa within the Oromia National Regional State (ONRS). Wonji-Shoa $\left(8^{\circ}\right.$ $21^{\prime} 3.84^{\prime \prime}$ to $8^{\circ} 27^{\prime} 25.86^{\prime \prime} \mathrm{N}$ and $39^{\circ} 12^{\prime} 13.28^{\prime}$ “ to $39^{\circ} 18^{\prime} 34.46$ “E), and Metahara ( $8^{\circ} 45^{\prime} 4.16^{\prime}$ ” to $8^{\circ} 53^{\prime} 20.75^{\prime} \mathrm{N}$ and $39^{\circ} 49^{\prime}$ 10.74 " to $40^{\circ} 0.21$ ' $\left.1.48^{\prime \prime} \mathrm{E}\right)$ were located in the central part of the East African Rift Valley system in the Awash River Basin, while Finchaa $\left(9^{\circ} 21^{\prime} 18.12^{\prime \prime}\right.$ to $9^{\circ} 25^{\prime} 23.01^{\prime \prime} \mathrm{N}$ and $39^{\circ} 11^{\prime} 8.85^{\prime \prime}$ to $39^{\circ} 15^{\prime} 3.2^{\prime \prime} \mathrm{E}$ ) was situated in the valley of southwestern highlands of Ethiopia in the Abay River Basin. The total area of land covered with cane during the study time were about 7050, 10,248 and 9,000 ha, respectively, for Wonji-Shoa, Metahara and Finchaa Sugar Estates [18].

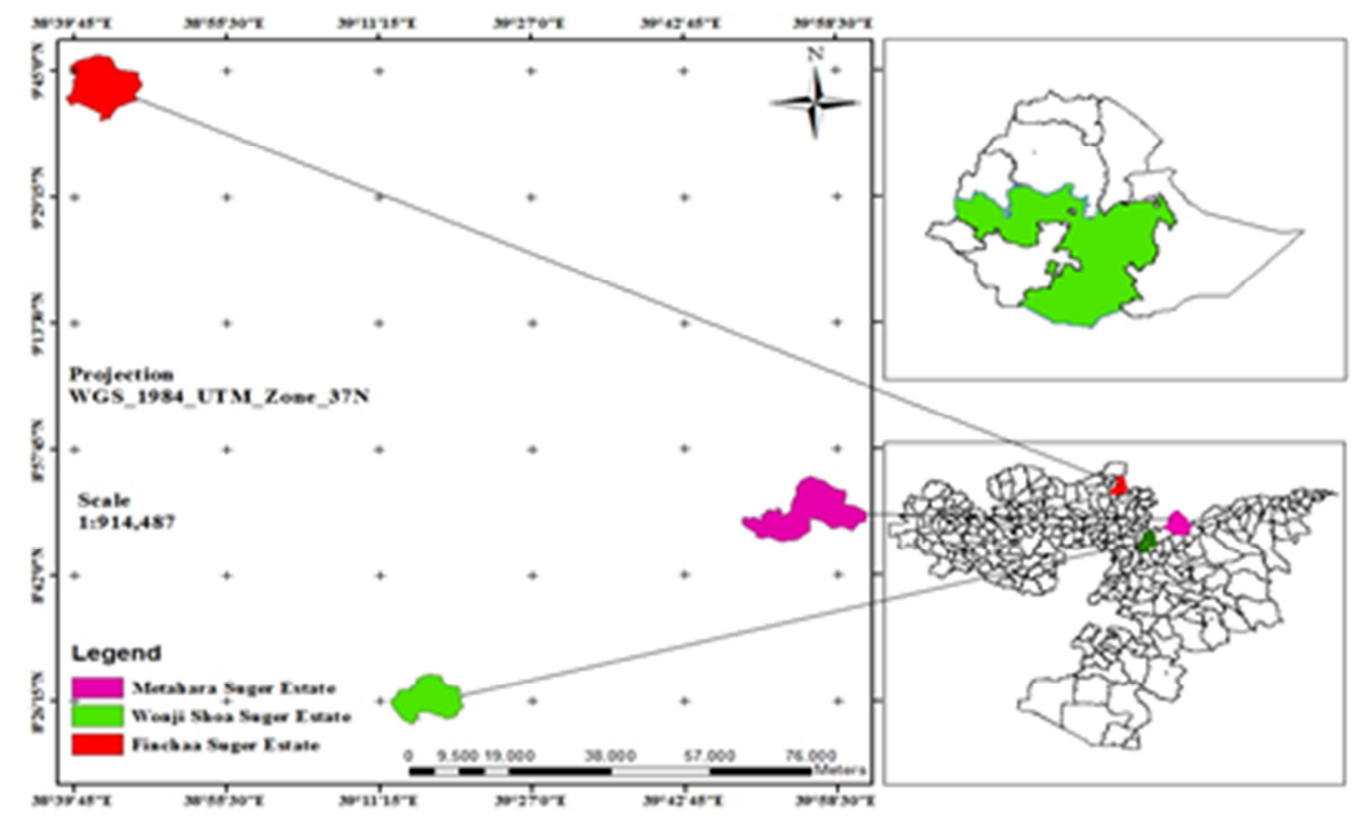

Figure 1. Location map of Finchaa, Metahara and Wonji-Shoa Sugar Estates in Ethiopia. 
The climate at Wonji-Shoa and Metahara was semiarid, while Finchaa has sub humid climatic condition. Ten years (2003-2013) climatic data (Figures $2 \mathrm{a}$ and b) of the WonjiShoa and Metahara Estates indicated that the areas have a bimodal rainfall pattern in which small rain is received from February to April, while the main rainy season that contributes a significant proportion of the total annual rainfall is received during June to September. Nevertheless, ten years (2003-2013) climatic data from Finchaa Meteorological Station also showed unimodal rainfall pattern, in which majority of the annual rain falls between May to September (Figure $2 \mathrm{c}$ ). The mean of ten years annual rainfall of the study areas are 831.47, 539.39, and $1399.72 \mathrm{~mm}$ for WonjiShoa, Metahara and Finchaa, respectively [19]. Moreover, average maximum and minimum temperature of the three estates were about 15.19 and $27.57^{\circ} \mathrm{C}$ for Wonji-Shoa, 17.73 and $33.24^{\circ} \mathrm{C}$ for Metahara and 14.40 and $30.54^{\circ} \mathrm{C}$ for Finchaa [20].

The major geologic materials of Wonji-Shoa, Metahara and Finchaa Estates were developed under tropical hot condition from alluvium-colluvium parent materials which include basic volcanic rocks such as basalt and limestone, acidic volcanic rocks such as granite and sandstone as well as recent and ancient alluvial soils developed from materials laid down by river systems [21]. The majority areas of the estates were occupied by Vertisols and Fluvisols [22] at Wonji-Shoa, Vertisols and Luvisols at Finchaa [23] and Calcaric Cambisols at Metahara Estate [24].
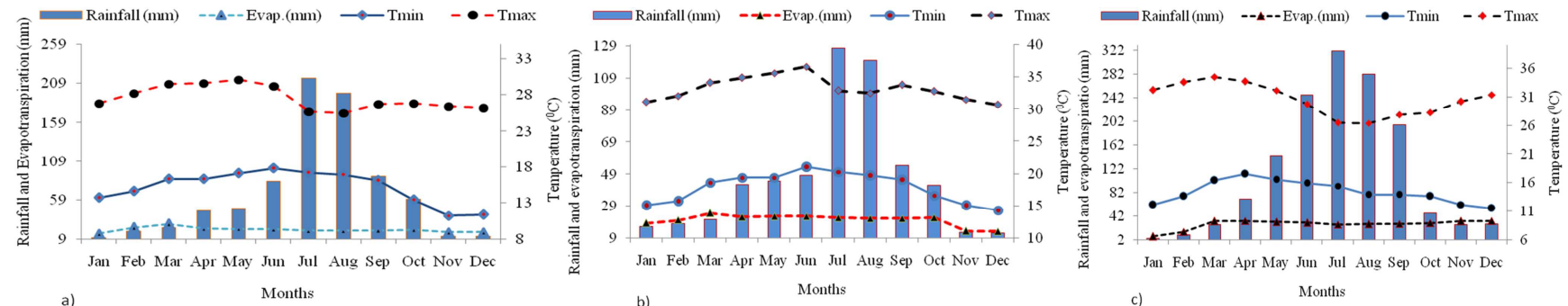

Figure 2. Ten years mean monthly rainfall, evapotranspiration (Evap), and monthly minimum (Min) and maximum (Max) temperatures of Wonji-Shoa (a), Metahara (b) and Finchaa Estates (c).

The soils of the estates are classified in to 13 soil management units where five, six and two soil management units belong, respectively, to Wonji-Shoa, Metahara and Finchaa. Wonji-Shoa and Metahara Estates classify their soils based on water retention at pF2 $(10 \mathrm{kPa})$ matrix potential and soil texture into light and heavy-textured soils. The light textured soils, designated by $\mathrm{B}_{1.4}$ and $\mathrm{C}_{1}$ at Wonji-Shoa, and Classes 1-3at Metaharahave low water holding capacity and, thus, require more frequent irrigation. On the other hand, the heavy-textured soils $\left(\mathrm{A}_{1}, \mathrm{~A}_{2}\right.$, and $\mathrm{BA}_{2}$ of Wonji-Shoa and Classes 4-6 of Metahara) are characterized by generally high water holding capacity and, thus, require less frequent irrigation. More than 95 percent of the cultivated and irrigated land soils in Finchaa are grouped in to Luvisols and Vertisols and are in use for different agricultural field operations $[25,26]$. However, in Finchaa, the same irrigation application rate and interval was in use for both soil types.

The mean altitude of the three estates was 1540, 950, and 1500 meters above sea level (m.a.s.l) for Wonji-Shoa, Metahara, and Finchaa, respectively. In Wonji-Shoa and Metahara Estates, the slope of the fields was generally very gentle and regular which makes them suitable for gravity irrigation [27]. On the other hand, the Finchaa Estate farm was dominated by a gently undulating surface with a general slope of 1 to 8 percent northwards. This made the preferred irrigation system at Finchaa to be sprinkler irrigation [28]. The sources of water for irrigation were Awash River for Wonji-Shoa and Metahara, and Finchaa River for the Finchaa Estate. The major crop of the estates is sugarcane, while haricot bean and crotalaria are minor crops (for Wonji-Shoa), oranges, mangoes, lemons and grape fruits (for Metahara) and sesame and horticultural crops (for Finchaa) Estates. The average length of growing period of sugarcane (plant cane) in the study area is about 22 months.

\subsection{Sites Selection, Sampling and Sample Preparation}

Soil sampling was done from plantation fields that have been under sugarcane cultivation for 20, 49 and 62 years, respectively, at Finchaa, Metahara, and Wonji-Shoa Estates. The soil sampling sites for this experiment were selected based on their clay contents. Nine soil Sampling sites, three from each estate, were selected. While, soils from three estates were categorized as heavy clays or clay contents $>$ $55 \%$, medium clay or between $45-55 \%$ clay contents, and light clay or between $35-40 \%$ clay contents (Table 1) as suggested by Hazelton and Murphy [29]. Accordingly, from the selected sites, a total of nine undisturbed core samples $(5$ $\mathrm{cm}$ height and $5 \mathrm{~cm}$ diameter) and composite soil samples were collected from the top $0.3 \mathrm{~m}$ of each estate.

Sugarcane residues were added to soils at rates of $0,7.75 \mathrm{~g}$ of residues per $\mathrm{kg}$ of soils. The amount of residue corresponds to 0 and $30 \mathrm{t} \mathrm{ha}^{-1}$ (depth of $0.3 \mathrm{~m}$ ) across soils with three clay levels. While for filter cake compost, the test of parameters was done only for heavy clay soil type across two levels $\left(0\right.$ and $\left.30 \mathrm{t} \mathrm{ha}^{-1}\right)$ of filter cake compost. For proctor test, plastic limit and liquid limit analyses, soils from $1 \mathrm{~m}^{2}$ pit to a depth of $30 \mathrm{~cm}$ was mixed with $3 \mathrm{~kg}$ filter cake and filter cake compost separately and $50 \mathrm{~kg}$ samples were collected for filter cake and filter cake compost from each sampling site. Finally, one and half quintal pure soils and 
filter cake mixed soils for each clay level and another one and half quintals filter cake compost mixed soils (only for heavy clay) were packed and transported to soil test laboratory in Addis Ababa.

Air dried filter cake compost were prepared by windrow aerobic composting as outlined by Mahamuni and Patil [30]. Both filter cake and filter cake compost were mixed with soil at moisture content of 52 and $45 \%$, respectively. These soil samples were air dried, homogenized and passed through 2 $\mathrm{mm}$ sieve, $0.43 \mathrm{~mm}$ sieve (for plastic limit and liquid limit), $4.75 \mathrm{~mm}$ sieve (for proctor test) and $0.50 \mathrm{~mm}$ sieve for analysis of soil organic carbon and total nitrogen. Analysis of the selected soil physical and chemical properties was done in Wonji central laboratory, Metahara and Finchaa station laboratories and Debrezeit research center. The analysis for plastic limit and liquid limit, and proctor test were carried out in the Transport and Construction Share Company Soil Test Laboratory in Addis Ababa.

\subsection{Laboratory Analysis}

Soil physical analysis: Particle size distribution was determined by the Bouyoucos hydrometer method as described by Okaleboet al. [31]. The textural class was determined using the USDA soil textural triangle [32]. Bulk density was determined from the undisturbed samples using the core method as described by Jamison et al. [33], whereas particle density $\left(\rho_{p}\right)$ was determined using the pycnometer method following the procedure described in Raoet al.[34]. Total porosity was calculated from the values of bulk density and particle density using the methods described by Rowell [35]. Liquid limits (LL), plastic limits (PL) and proctor test were determined following the procedures outlined by American Society of Testing Materials [36]. Water content at all points of compaction including water content that results in the greatest density (CMC) was determined gravimetrically as described by Reynolds [37]. Moreover, plastic index was taken as the numerical difference between the liquid limit and the plastic limit [38].

In the laboratory, a modified proctor test was applied at different water contents to obtain the maximum dry density of the mixtures and soils without residues [39]. The dry bulk density was calculated from the soil mass in the proctor cylinder and the water content that was measured after compaction. The samples were compacted by dropping a 4.5 $\mathrm{kg}$ rammer 125 times from a height of $45 \mathrm{~cm}$. The compaction load was chosen to simulate the heaviest tractor used during sugarcane cultivation at some of the Ethiopian Sugar Estates (e.g. Metahara Estate). The soil and residue mixtures were mixed thoroughly two months before laboratory analysis. The rates of amendments were selected based on the rates recommended by Girma [40] used presently in the three Ethiopian Sugarcane Estates (30 t.ha ${ }^{-1}$ for filter cake).

\subsection{Soil Chemical Analysis}

The $\mathrm{pH}$ of the soils was measured in water (1: 2.5 soil: water ratio) by glass electrode $\mathrm{pH}$ meter [41]. Soil organic carbon was determined by the wet digestion method following the procedure of Walkley and Black [42]. The total nitrogen was determined by the Kjeldal method as described by Jackson [43], while the available phosphorus was extracted according to Olsen's method [44] for all estate soils except Bray II [45] for Finchaa $(\mathrm{pH}<6)$ extraction methods. The $\mathrm{P}$ extracted with the different methods was measured by spectrophotometer following the procedures described by Murphy and Riley [46]. Physicochemical characteristics of the soils are summarized in Table 1 below.

Table 1. Mean values of selected soil physicochemical properties of soils with three levels of clay content.

\begin{tabular}{llll}
\hline \multirow{2}{*}{ Soil parameters } & Soil clay content levels & & \\
\cline { 2 - 4 } & Light clay & Medium clay & Heavy clay \\
\hline Sand $(\%)$ & 43.00 & 22.00 & 12.00 \\
Clay $(\%)$ & 39.00 & 54.00 & 70.50 \\
Silt $(\%)$ & 18.00 & 24.00 & 17.50 \\
Textural class & Clay loam & clay & clay \\
Bulk density $\left(\mathrm{g} \mathrm{cm}^{-3}\right)$ & 1.41 & 1.28 & 1.19 \\
Particle density $\left(\mathrm{g} \mathrm{cm}^{-3}\right)$ & 2.50 & 2.43 & 2.22 \\
Liquid limit $(\%)$ & 56.00 & 56.50 & 76.50 \\
Plastic limit $(\%)$ & 27.00 & 27.66 & 31.50 \\
Plastic index $(\%)$ & 29.00 & 28.84 & 45.00 \\
Soil organic carbon $(\%)$ & 1.04 & 1.30 & 1.68 \\
Soil pH & 5.82 & 8.17 & 7.83 \\
Soil total nitrogen $(\%)$ & 0.085 & 0.09 & 0.10 \\
Available P $\left(\mathrm{mg} \mathrm{kg} \mathrm{kg}^{-1}\right)$ & 5.40 & 6.79 & 9.20 \\
\hline
\end{tabular}

\subsection{Compost Analysis}

The compost sample was analyzed for $\mathrm{pH}$, total $\mathrm{N}$, available $\mathrm{P}$, available $\mathrm{K}$, and soil $\mathrm{OC}$ following the standard procedures. Soil $\mathrm{pH}$ was measured from suspension of $1: 2.5$ of soil to water ratio using a glass electrode attached to digital $\mathrm{pH}$ meter [47]. Total Nitrogen content of compost was analyzed using modified Kjeldahl digestion, distillation and titration method as described by Nelson and Sommers [48]. Furthermore, available phosphorus (P) and exchangeable potassium (K) were determined by dry ashing method [49]. Organic carbon was determined using Carmo and Silva [50] method. The analysis results for compost composition are described in Table 2 below. 
Table 2. Characterization of selected chemical parameters of sugarcane industry residues filter cake and filter cake composts.

\begin{tabular}{lll}
\hline Parameters & Filter cake & Filter cake compost \\
\hline $\mathrm{pH}$ & 6.56 & 8.20 \\
$\mathrm{OC}(\%)$ & 24.71 & 19.90 \\
Total N (\%) & 1.13 & 2.21 \\
$\mathrm{C}: \mathrm{N}$ ratio & 21.86 & 9.00 \\
$\mathrm{P}(\%)$ & 1.42 & 2.50 \\
$\mathrm{~K}(\%)$ & 0.65 & 4.62 \\
\hline
\end{tabular}

Data Analysis and Interpretations: A complete factorial randomized design with three replications was used to analysis the variation of proctor parameters. Soil proctor test parameter data were subjected to analysis of variance using the GLM procedure of SAS software [51]. For those parameters that were significant, mean separation was done using the Fisher's least significant difference (LSD) and correlation analyses were conducted in order to detect the association between the proctor parameters.

\section{Results and Discussion}

\subsection{Effects of Different Soil Clay Content Levels}

Filter Cake and Filter Cake Compost on Selected Soil Physicochemical Characteristics of the Soils in the Study Area: The results of analysis of variance (ANOVA) revealed that maximum dry density, critical moisture content and total porosity were significantly $(\mathrm{P}<0.05)$ affected by both soil clay content levels and filter cake. Similarly, maximum dry density, total porosity and critical moisture content were affected also by filter cake compost. None of the soil properties were affected by the interaction effects (Tables 3 and 4).

\subsection{Effects of Different Soil Clay Content Levelson Proctor Parameters}

For this investigation, soil moisture content versus dry density relationship was determined by means of the modified proctor compaction test (Figure 3). Independent of soil type, dry density increased gradually up to the critical moisture content (the amount of water required to produce a maximum dry density) (CMC) to maximum dry density (MDD) and then decreased with increasing water content.

Results of this study showed that critical water content, maximum dry density and total porosity were significantly ( $\mathrm{P}$ $<0.05$ ) affected by soil clay content levels (Table 3 ). It was found to vary from 15.94 to $28.60 \%, 1.40$ to $1.72 \mathrm{~g} \mathrm{~cm}^{-3}$ and 32.83 to $41.33 \%$, respectively, for critical water content, maximum dry density and total porosity among the soil types. The difference in $\mathrm{CMC}$, MDD and total porosity among the soil types may be attributed to the variation in organic matter and clay contents among the soil types (Tables 1 and 3 ). This finding is in agreement with Nhantumbo and Cambule [52] who stated that proctor parameters variations were largely associated with changes in clay content and organic matter content.

The maximum dry densities $\left(1.72,1.68\right.$ and $\left.1.40 \mathrm{~g} \mathrm{~cm}^{-3}\right)$ were achieved at $15.94,25$ and $28.60 \%$ soil water contents, respectively, for light, medium and heavy clay soils and can be expressed as $0.60,0.9$ and 0.91 plastic limits (Tables 1, 3 and Figure 3). This shows that maximum dry bulk density with no residue added was occurred at moisture content below the PL and critical moisture content for the maximum dry density increased as the clay content increases (Tables 1 and 3). In line with this, Wesley et al. [53] also reported increase of CMC along with increase of clay content.

\subsection{Effects of Filter Cake Incorporation on Proctor Parameters}

Incorporation of filter cake at the rate of $30 \mathrm{t} \mathrm{ha}^{-1}$ significantly $(\mathrm{P}<0.05)$ affected maximum dry density, critical moisture content and total porosity (Table 3 ). The mean value of maximum dry density (MDD) for soils without filter cake was significantly $(\mathrm{P}<0.05)$ different from the mean value of MDD of soils into which filter cake was incorporated (Table 3 ). Maximum dry density was changed from 1.93 to $1.58 \mathrm{~g} \mathrm{~cm}^{-3}$ (light clay), 1.78 to $1.51 \mathrm{~g} \mathrm{~cm}^{-3}$ (medium clay) and 1.42 to 1.38 $\mathrm{g} \mathrm{cm}^{-3}$ (heavy clay) after filter cake incorporation. Accordingly, incorporation of filter cake reduced the maximum mean dry bulk density by $18.13 \%$ for light clay, $15.17 \%$ for medium clay and $4 \%$ for heavy clay soil below the control (Table 3 ). The lower maximum dry density recorded after incorporation of filter cake could be attributed to the lower density of filter cake that can reduce the overall bulk density of the soil and the likely high elasticity of this organic residue.

Table 3. Effects of filter cake (the upper table) and soil types (lower table) on proctor test parameters of the soils.

\begin{tabular}{|c|c|c|c|}
\hline FC (t/ha) & $\operatorname{MDD}\left(\mathrm{g} \mathrm{cm}^{-3}\right)$ & CMC (\%) & $f(\%)$ \\
\hline 0 & $1.71^{\mathrm{a}}$ & $21.58^{\mathrm{b}}$ & $32.67^{b}$ \\
\hline 30 & $1.49^{\mathrm{b}}$ & $26.55^{\mathrm{a}}$ & $39.44^{\mathrm{a}}$ \\
\hline LSD & 0.08 & 1.69 & 0.04 \\
\hline Soil types & $\operatorname{MDD}\left(\mathrm{g} \mathrm{cm}^{-3}\right)$ & CMC (\%) & $f(\%)$ \\
\hline Light clay & $1.72^{\mathrm{a}}$ & $15.94^{b}$ & $32.83^{b}$ \\
\hline Medium clay & $1.68^{\mathrm{a}}$ & $25^{\mathrm{a}}$ & $34.00^{\mathrm{a}}$ \\
\hline Heavy clay & $1.40^{\mathrm{b}}$ & $28.60^{\mathrm{a}}$ & $41.33^{\mathrm{a}}$ \\
\hline LSD & 0.09 & 2.07 & 0.05 \\
\hline
\end{tabular}

Means in a column with the same letters are not significantly different from each other at $\mathrm{P}<0.05, \mathrm{~ns}=$ non-significant

Nevertheless, the critical moisture content at which the maximum dry density was obtained changed significantly ( $P$ $<0.05$ ) as a result of filter cake incorporation (Table 3). The critical moisture content at which MDD was attained ranged from 13.63 to $18.25 \%, 25$ to $27.03 \%$, and 26.11 to $31.1 \%$, respectively for light clay, medium clay and heavy clay and increased by $33.89,22.8$, and $19.2 \%$ due to incorporation of filter cake, respectively, in light, medium and heavy clay soils (Tables 3 and 4). This indicates the favorable effect the filter cake had on water retention capacities of the soils.

The results from three cohesive soils clearly indicated that filter cake was most effective in reducing soil compactibility at moisture contents less than PL (at 0.7, 0.97 and 0.98 PL, respectively, for light clay, medium clay and heavy clay). 
Likewise, the effect of water content is more pronounced than filter cake on dry bulk density at water content higher than PL. This might be because at high water content nearly all the pores were saturated with water and the elasticity behaviour of filter cake was low. This finding is in line with the research reported by Jianget al. [54] who showed the effectiveness of organic manure at low water content due to its high elasticity behaviour.

Furthermore, at water content lower than PL filter cake residue was more effective in reducing soil compactibility compared to water content higher than PL. The possible mechanisms that may explain the reduction of soil compactibility due to filter cake are related to its high elasticity, dilution effect and high water retention of this residue. These processes can increase the resilence of soils against external forces. The effectiveness of sugarcane residues in reducing soil maximum dry density at different water contents was also reported by Tesfayeet al. [55]. These authors attributed this effectiveness to the generally low density of the filter cake and their positive effect on encouraging soil aggregation, which in turn increases total porosity.

Table 4. Distribution of maximum dry density, critical moisture content and soil total porosity across soil types and two levels of filter cake (interaction effect).

\begin{tabular}{|c|c|c|c|c|}
\hline \multirow{2}{*}{ Soil parameters } & \multirow{2}{*}{ Filter cake $\left(\mathrm{t} \mathrm{ha}^{-1}\right)$} & \multicolumn{3}{|l|}{ Soil types } \\
\hline & & Light clay & Medium clay & Heavy clay \\
\hline \multirow{3}{*}{$\operatorname{MDD}\left(\mathrm{g} \mathrm{cm}^{-3}\right)$} & 0 & $1.93^{\mathrm{a}}$ & $1.78^{\mathrm{a}}$ & $1.42^{\mathrm{a}}$ \\
\hline & 30 & $1.58^{\mathrm{a}}$ & $1.51^{\mathrm{a}}$ & $1.38^{\mathrm{a}}$ \\
\hline & LSD & $\mathrm{ns}$ & $\mathrm{ns}$ & ns \\
\hline \multirow{3}{*}{ Total porosity (\%) } & 0 & $29.00^{\mathrm{a}}$ & $29.00^{\mathrm{a}}$ & $41.00^{\mathrm{a}}$ \\
\hline & 30 & $38.00^{\mathrm{a}}$ & $39.00^{\mathrm{a}}$ & $42.00^{\mathrm{a}}$ \\
\hline & LSD & ns & ns & ns \\
\hline \multirow{3}{*}{$\mathrm{CMC}(\%)$} & 0 & $13.63^{\mathrm{a}}$ & $22.00^{\mathrm{a}}$ & $26.11^{\mathrm{a}}$ \\
\hline & 30 & $18.25^{\mathrm{a}}$ & $27.03^{\mathrm{a}}$ & $31.10^{\mathrm{a}}$ \\
\hline & LSD & ns & ns & ns \\
\hline
\end{tabular}

$\mathrm{MDD}=$ maximum dry density, $\mathrm{CMC}=$ critical moisture content, $\mathrm{LSD}=$ least significant difference, $\mathrm{ns}=$ not significant, and means with the same letters are not significantly different
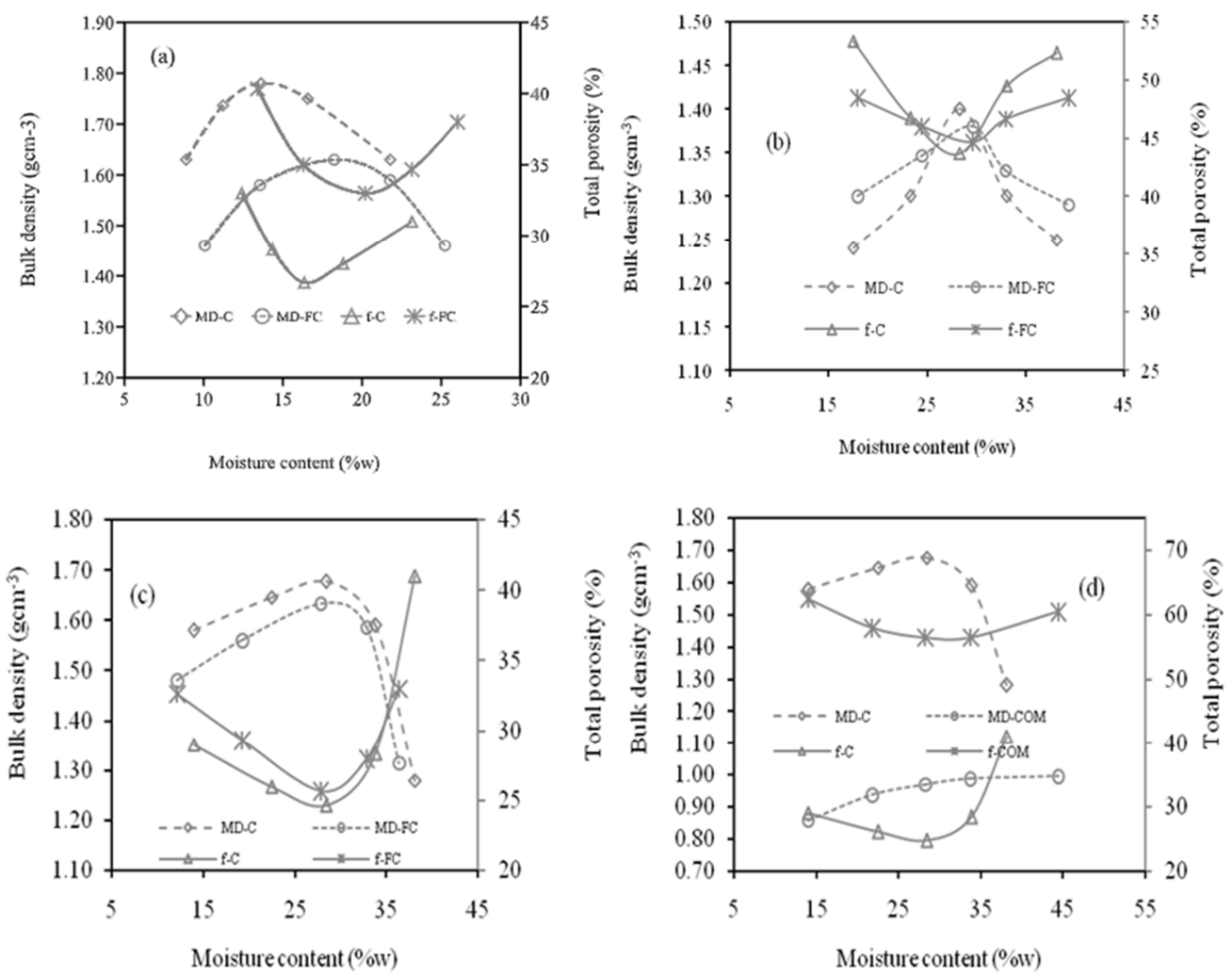

Figure 3. The relationship among moisture content, dry bulk density and total porosity at two levels of sugarcane residues of (a) control and filter cake in light clay soil; (b) control and filter cake in heavyclaysoil; (c) control and filter cake in medium clay soil; (d) control and filter cake compost in heavy clay soil.

MD-C=dry density of control; MD-FC=dry density of filter cake: $f-C=$ porosity of control; $f-F C=$ porosity of filter cake; MD-COM=dry density of filter cake compost; f-COM=porosity of filter cake compost. 
Total porosity at MDD was significantly $(\mathrm{P}<0.05)$ affected by filter cake incorporation into soils. The mean value of total porosity at MDD after filter cake incorporation was 38, 39 and $42 \%$, respectively, for light, medium and heavy clay soils (Table 4). The significant variation of total porosity at MDD after filter cake incorporation among different soils may be due to different values of MDD and particle density of soil types. This may be confirmed by the strong negative correlation $\left(\mathrm{r}=-0.73^{* * *}\right)$ between total porosity and MDD (Table 6). Figure 3 illustrates the relationship among moisture content, dry bulk density and total porosity at two levels of sugarcane residues using the modified proctor test.

\subsection{Effects of Filter Cake Compost Incorporation on Proctor Parameters}

Unlike the results obtained from incorporation of filter cake, only maximum dry density and total porosity were highly influenced by incorporation of filter cake compost, while critical moisture content at which the MDD was obtained vary slightly due to filter cake compost incorporation (Table 5). In accordance with this, the MDD of the soils that received $30 \mathrm{tha}^{-1}$ filter cake compost was lower than the MDD of the untreated soils. Consequently, the filter cake compost reduced the maximum dry density of soils by about 27.6\%as compared to the control (Table 5). The difference in maximum dry density between soils without and with incorporation of compost might be due to high elasticity and low bulk density of filter cake compost. Similar finding was reported by Chamen et al. [56] in that organic matters with high elasticity are effective in reducing soil compactibilty.

On the other hand, the mean total porosity of the soils into which $30 \mathrm{t} \mathrm{ha}^{-1}$ filter cake compost incorporated was higher than that of the untreated soil. Incorporation of filter cake compost improved the total porosity by $46.9 \%$. The higher total porosity in residue incorporated soils may be attributed to the reduction in maximum dry density due to filter cake compost incorporation. This could be evidenced by significant and negative correlation $\left(\mathrm{r}=-0.87^{*}\right)$ of total porosity with maximum dry density (Table 6). Furthermore, reduction in maximum dry density due to compost addition is an indication of increased porosity.

Filter cake and filter cake compost reduced the maximum dry density of heavy clay soil by 4 and $27.6 \%$, respectively, as compared to control. Nevertheless, this residues increased total porosity at critical moisture content, respectively, by 2.44 and $46.9 \%$ over the control for heavy clay soils. This indicated that filter cake compost reduced maximum soil compactibility more than that obtained by incorporating filter cake. This may be attributed to the high elastic property of filter cake compost than filter cake since it is a highly decomposed organic matter source (Table 2). This shows that filter cake compost is more effective in reducing soil compactibility than filter cake. In line with this, Thomas et al. [57] also reported that highly decomposed residues reduced soil compatibility more than the slightly decomposed residues. Filter cake compost applied at the rate of $30 \mathrm{tha}^{-1}$ to heavy clay soils reduced the soil compactibility at water content of 0.93 PL. The result was also in agreement with Meyer and Antwerpen [58] who reported effectiveness of sugarcane residues in reducing soil compactibility at water content lower than PL.

The results from this study indicated that compaction of top soil can be reduced by sugarcane residue incorporation. This is very important for growth of sugarcane since most of sugarcane root populations are found in the topsoil layer. In consent with this finding, Tesfayeet al. [59] reported that $90 \%$ of the root population of sugarcane is found in the upper $60 \mathrm{~cm}$ of the soils in which most of the root distributions are restricted in top soil in Ethiopian Sugarcane Estates. Moreover, Barzegaret al. [59] and Usaborisut and Niyamapa [60] also reported that roots of sugarcane are mainly distributed in the top soil layers. Therefore, in the three soil types (light, medium and heavy clay) heavy machineries operatio

$\mathrm{n}$ during sugarcane seedbed preparation and harvesting may be used when soil moisture is below $0.60,0.9$ and 0.91 PL, respectively, for light, medium and heavy clay soils and when filter cake and filter cake compost are mixed with soils.

Table 5. Effects of filter cake compost on proctor test parameters of heavy clay soils.

\begin{tabular}{lllll}
\hline Soil type & Com $(\mathbf{t} / \mathbf{h a})$ & MDD $\left(\mathbf{g} / \mathbf{c m}^{3}\right)$ & CMC $(\%)$ & $\boldsymbol{f}(\%)$ \\
\hline \multirow{2}{*}{ Heavy clay } & 0 & 1.45 & 26.11 & 34.7 \\
& 30 & 1.05 & 29.27 & 51.00 \\
\hline
\end{tabular}

Com=compost, $\mathrm{MDD}=$ maximum dry density, $\mathrm{CMC}=$ critical moisture content, $\mathrm{f}=$ total porosity

It appears that in all the three soil clay content levels at $0 \mathrm{t}$ $\mathrm{ha}^{-1}$ and $30 \mathrm{t} \mathrm{ha}^{-1}$ of filter cake and filter cake compost application levels, the porosity attains a minimum value at critical moisture content. Filter cake increased total porosity at critical moisture content by $2.44 \%$ for heavy clay soils. However, filter cake compost increased total porosity of heavy clay soils by $46.9 \%$ as compared to the soil with no residue added to it. This makes filter cake compost better material in increasing total porosity and reducing soil compactibility in heavy clay soils. The relationship between soil moisture content and total porosity is shown in Figure 3.

Table 6. Pearson correlation analysis among proctor test parameters for soils treated with filter cake (upper table) and filter cake compost (lower table).

\begin{tabular}{llll}
\hline & MDD & CMC & $\boldsymbol{f}$ \\
\hline MDD & 1 & $0.43^{\mathrm{ns}}$ & $-0.73^{* * *}$ \\
CMC & 1 & $-0.45^{\mathrm{ns}}$ \\
$f$ & & & 1 \\
\hline & & & \\
\hline MDD & 1 & $\mathbf{C M C}$ & $\boldsymbol{f}$ \\
CMC & & $0.55^{\mathrm{ns}}$ & $-0.87^{*}$ \\
$f$ & & 1 & $-0.26^{\mathrm{ns}}$ \\
\hline
\end{tabular}

$\mathrm{MDD}=$ maximum dry density, $\mathrm{CMC}=$ critical moisture content, $\mathrm{f}=$ total porosity and $* * *, * *$ and $*=$ significant at $\mathrm{P}<0.001, \mathrm{P}<0.01$ and $\mathrm{P}<0.05$, respectively; ns $=$ not significant 


\section{Conclusion and Recommendation}

The results of this study showed that the maximum dry bulk density with no sugarcane residue added was achieved at 0.6 PL for light, 0.9 PL for medium and 0.91 PL for heavy clay. Filter cake incorporated at the rate of $30 \mathrm{t} \mathrm{ha}^{-1}$ reduced the soil compactibility induced by proctor test load at water content of 0.7 PL for light clay soils, 0.97 PL for medium clay and at water content of $0.98 \mathrm{PL}$ for the heavy clay soils. In all three soil types at $0 \mathrm{t} \mathrm{ha}^{-1}$ and $30 \mathrm{t} \mathrm{ha}^{-1}$ residue application levels, the total porosity attained a minimum value at critical moisture content and critical moisture content for the maximum dry density increased as the clay content increased. Filter cake and filter cake compost reduced the maximum dry density of heavy clay soil by 4 and $27.6 \%$, respectively, as compared to the control. Nevertheless, this residues increased total porosity at critical moisture content, respectively, by 2.44 and $46.9 \%$ over the control for heavy clay soils.

Therefore, based on the findings from three soils of different clay content it can be concluded that knowing the change in soil compactibility with water content changes help one to schedule farm trafficking and cultivation operations at the proper moisture content. Furthermore, sugarcane residue was most effective in reducing soil compactibility at moisture content less than PL compared to water content higher than PL. However, at the water content higher than PL the effect of moisture content on dry density is greater than the effects of sugarcane residues since at higher water contents nearly all pores will be occupied by water (saturation) and the elasticity behavior of sugarcane residue is low. Moreover, filter cake compost was more effective in reducing soil compactibility than filter cake and sugarcane residues application in the form of filter cake and its compost could help to achieve a relatively sustainable soil management and an increase in soil fertility.

Based on the findings and conclusions of this study the following recommendations are made:

Heavy machineries operation in the three soil types (light, medium and heavy clay soils) during sugarcane seedbed preparation and harvesting; shall be made when soil moisture is below $0.60,0.9$ and $0.91 \mathrm{PL}$, respectively, for light, medium and heavy clay soils and when either filter cake or filter cake compost is mixed with soils tentatively.

Nevertheless, in order to give conclusive recommendation further research studies are needed for more soil clay levels for the case of filter cake compost and more rates for both sugarcane residues.

\section{Conflict of Interests}

The authors declare that there is no conflict of interests regarding the publication of this paper.

\section{Acknowledgements}

The author of this article acknowledges the Ministry of Education for financing the study through Ambo and
Haramaya Universities. The contributions of Wonji-Shoa, Metahara and Finchaa Sugar Estates management staff members, data collectors and laboratory technicians was beyond that can be expressed in money and deserves marvelous appreciation.

\section{References}

[1] Ahmad, N., Hassan, F. and, Qadir, G. 2007. Effect of subsurface soil compaction and improvement measures on soil properties. International Journal Agriculture and Biology., 9: 509-13.

[2] Hamza, M. A. and Anderson, W. K. 2005. Soil compaction in cropping systems. A review of the nature, causes and possible solutions. Soil and Tillage Research, 82: 121-145.

[3] Alvarez, C. R.; Taboada, M. A., Gutiérrez, F. H.; Fernández, P. L. and Prystupa, P. 2009. Topsoil properties as affected by tillage systems in the rolling pampa region of Argentina. Soil Science Society of America Journal, 73: 242-1250.

[4] Hugar, M. G. and Soraganvi, S. V. 2014. Impact of Soil Organic carbon on Bulk Density and plasticity index of Arid Soils of Raichur. Karnataka, India.

[5] Ridge, R. 2013. Sugarcane Fertilizing for High Yield. IPI Bulletin No. 21. International Potash Institute, Coral Cove, Australia.

[6] Ambachew, D. and Abiy, F. 2009. Assessment of Some Soil physicochemical Properties of Soils of Wonji- Shoa, Metahara and Finchaa Sugarcane Plantations. Annual research report. Ethiopian Sugar Corporation Research and Training Service Division, Wonji, Ethiopia. pp. 118-130.

[7] Ambachew, D., Abiy, F., Zeleke, T. 2012. Correlation of Foliar Nutrient Status with Yield of Sugarcane Varieties at Different Crop Stages and Nitrogen Levels at Wonji-Shoa and Finchaa Sugarcane Plantations of Ethiopia. Ethiop. Journal of Applied Science Technololy. 3: 9-22.

[8] Ambachew, D. and Ademe, A. 2009. Determination of optimum nitrogen and phosphorus rate for sugarcane at Finchaa Sugarcane plantation. Proc. Ethiopian Sugar Ind. Biennial conf, 1: 117-125.

[9] Atsbeha, N. 2012. prediction of compaction characteristics from atterberg limits for fine-grained soils" Thesis for Master of Science degree, Faculty of Technology, Addis Ababa University.

[10] Diazzorita, M., Grove, J. H. and Perfect, E. 2001. Laboratory compaction of soils using a small mold procedure. Soil Science Society of America Journal, 65: 1593-1598.

[11] Krueger, M. K. 2011. The Michigan Cone Test: A Reliability Study. Msc Thesis, Michigan Technological University, Michigan, USA.

[12] Mari, G. R. and Changying, J. 2008. Influence of agricultural machinery traffic on soil compaction patterns, root development and plant growth, overview. American-Eurasian J. Agric. Environ. Sci., 3: 49-62.

[13] Barzegar A. R., Mahmoodi, S. H, Hamedi, F., Abdolvahabi, F. 2005. Long term sugarcane cultivation effects on physical properties of fine textured soils. Journal of Agricultural Science Technology, 7: 59-68. 
[14] Datta, S. P., R. K. Rattan and S. Chandra, 2010. Labile soil organic carbon, soil fertility and crop productivity as influenced by manure and mineral fertilizers in the tropics. Journal of Plant Nutrition and Soil Science, 173: 715-726.

[15] Pisa, C. and M. Wuta, 2013. Evaluation of composting performance ofmixtures of chicken blood and maize stover in Harare, Zimbabwe. Int. J. Recycl. Organic Waste Agriculture, $2(5): 1-11$.

[16] Tesfaye, W., Kibebew, K., Bobe, B., Melesse, T. and Teklu, E. 2020. Effects of Compaction at Different Moisture Contents on Selected Soil Properties and Sugarcane Growth and Sugar Yield at Metahara Sugar Estate. American Journal of Agricultural Research, 15: 78.

[17] Zhang, H., Hartge, K. H., Ringe, H. 1997. Effectiveness of organic matter incorporation in reducing soil compactibility. Soil Science Society of America Journal, 61: 239-245.

[18] ESC (Ethiopian Sugar Corporations). 2013. Annual report. Ethiopian Sugar Corporation Research and Training Service Division, Addis Ababa, Ethiopia.

[19] ESC (Ethiopian Sugar Corporations). 2014. Ten Years (20042014) Climatic Data Obtained from the National Meteorological Agency of Wonji-Shoa, Metahara and Finchaa Stations. Ethiopian Sugar Corporation Research and Training Service Division, Addis Ababa, Ethiopia.

[20] ESC (Ethiopian Sugar Corporations). 2015. Ten Years (20042014) Climatic Data Obtained from the National Meteorological Agency of Wonji-Shoa, Metahara and Finchaa Stations. Ethiopian Sugar Corporation Research and Training Service Division, Addis Ababa, Ethiopia.

[21] Tesfaye, W., Kibebew, K., Bobe, B., Melesse, T. and Teklu, E 2016. Effects of long term mechanized sugarcane cultivation and soil compactibilityamelorative measures on selected soil properties and sugar yield at three Ethiopian Sugar Estates. PhD Thesis, Haramaya University, Haramaya, Ethiopia. pp. 202.

[22] APECS (Agrima Project Engineering and Consultancy Services). 1987. A Report on the Agricultural Research Services of the Ethiopian Sugar Corporation (ESC). Matha Private, Bombay, India. pp. 1-414.

[23] BAI (Booker Agricultural International) in association with Generation Integrated Rural Development Consultant. 2009. Re-evaluation of the Plantation Soils at Metahara Sugar Factory. Final Report. BAI, London, England.

[24] Zeleke, T. 2008. Characterization of soil management classes of Metahara Sugar Estate in terms of their physical and hydraulic properties. MSc Thesis, Haramaya University, Haramaya, Ethiopia.

[25] Tadesse, N. 2004. Summary of Metahara Sugar Factory Weather Data for the Year 2004 and Average of the Last Ten Years (1993-2004). Ethiopian Sugar Industry Support Center Research and Training Service Division, Wonji, Ethiopia.

[26] Ademe, A. 2009. Response of Sugarcane to Composted Filter Cake with Vinasse and Inorganic Fertilizers at Finchaa Sugar Estate. Annual research report. Ethiopian Sugar Corporation Research and Training Service Division, Wonji, Ethiopia.

[27] Michael, M. and Seleshi, B. 2007. Irrigation Practices in Ethiopia: Characteristics of Selected Irrigation Schemes. Integrated Water Management Institute, Colombo, Srilanka.
[28] Tesfaye, W., Kibebew, K., Bobe, B., Melesse, T and Teklu, E., 2018. Long Term Effects of Cultivation on Physicochemical Properties of Soils at Metahara Sugar Estate. AmericanEurasian Journal of Agricultural Research, 18: 246-257.

[29] Hazelton, P. and Murphy, B. 2007. Interpreting Soil Test Results: What Do All the Numbers Mean? 2nd ed. CSIRO Publishing, Colling wood, Australia. pp. 169.

[30] Mahamuni, S. V. and Patil, A. S. 2012. Microbial Consortium Treatment to Distillery Spent Wash and Press mud Cake Through Pit and Windrow System of Composting. Shardabai Pawar Mahila College, Maharashtra, India.

[31] Okalebo, J. R., Gathua, K. W. and Womer, P. L. 2002. Laboratory Methods of Soil and Plant Analyses. A Working Manual, 2nd ed. TSBF -CIAT and SACRED Africa, Nairobi, Kenya.

[32] Soil Survey Staff. (1999). A basic system of soil classification for making and interpreting soil survey. Agricultural Handbook. 436. U.S. Gov. Print. Office, Washington, DC.

[33] Jamison, V. C., Weaver, H. H. and Reed, I. F. 1950. A hammer-driven soil core sampler. Soil Science, 69: 487-496.

[34] Rao, M., Singa, P. and Raju, M. J. 2005. Laboratory Manual on Soil Physical Properties, $1^{\text {st }}$ edition. BS Publications, New Delhi, India.

[35] Rowell, D. L. 1994. Soil Science: Method and applications. Longman Scientific and Technical, Longman Group UK Limited Addison, Wesley, England. pp. 350.

[36] ASTM (American Society for Testing Materials). 2007. Annual Book of ASTM Standards. ASTM, Philadelphia, USA.

[37] Reynolds, S. G. 1970. The gravimetric method of soil moisture determination part I: a study of equipment, and methodological problems. Journal of Hydrology, 11: 258-273.

[38] Habtamu, K. 2006. Examining atterberg limits for expansive soils. MSc Thesis, Addis Ababa. University, Addis Ababa, Ethiopia.

[39] Lindsey, M. R. 2009. Establishing soil compaction thresholds for the M1A1 Abrams Tank at Camp Minden, Louisiana. PhD Thesis, Louisiana State University, Louisiana, USA. pp. 163

[40] Girma, A. 2009. Effect of filter cake and mineral fertilizers on yield of plant cane in the sugarcane plantations of Ethiopia. Proc. Ethiop. Sugar. Ind. Bienn. Conf., 1: 126-136.

[41] McLean, E. O. (1982). Soil pH and lime requirement. In: Page, A. L. (Ed.), Methods of Soil Analysis. Chemical and Microbiological Properties. Part 2. Agronomy Series No. 9. ASA, SSSA, Madison, USA, 199-234.

[42] Walkly, A. and Black, I. A. 1934. An examination of digestion method for determining soil organic matter and a proposed modification of the Chromic Acid Titration. Soil Science, 37: 29-38.

[43] Jackson, M. L. 1958. Soil Chemical Analysis. Prentice Hall, Inc., Englewood Cliffs. New Jersey.

[44] Olsen, S. R., Cole, C. V., Watanabe, L. and Dean, A. 1954. Estimation of Available $\mathrm{P}$ in Soils by Extraction with $\mathrm{NaHCO}_{3}$. USDA Cir. 939, US Government Printing Office, Washington D. C., USA. 
[45] Bray, R., and Kurz, L. (1945). Determination of total, organic and available forms of phosphorous in soil. Soil science Journal, 59: 39-45.

[46] Murphy, J. and Riley, J. P. 1962. A modified single solution method for the determination of phosphorus in natural waters. Analytica Chimica Acta, 27: 31-36.

[47] Van Reeuwijk, L. P. 1992. Procedures for soil analysis. International soil reference and information center (ISRIC) Wageningen, The Netherlands. $\mathrm{p} 23$.

[48] Nelson, D. W. and Sommers, L. E. 1973. Determination of Total Nitrogen in Plant Material. Agronomy Journal, 65: 109112.

[49] Chapman, H. and Pratt. (1961). Methods of analysis for soils, plant and water. University California, Berkeley.

[50] Carmo, D. L.; Silva, C. A. 2012. Quantification methods of carbon and organic matter in organic residues. Revista Brasileira de Ciência do Solo, 36: 1211-1220.

[51] SAS (Statistical Analysis System). 2002. SAS Version 9.1.3. SAS Institute Inc., Cary, NC, USA.

[52] Nhantumbo, A. B. and Cambule, A. H. 2006. Bulk density test as a function of texture for agricultural soils in Maputo Province of Mozanbique. Soil and Tillage Research, 87: 231239 .

[53] Wesley, T., Ndiema, C., Mutai, E. 2015. Assessment of Soil Compaction Levels by Farm Machineryin Cultivated Fields of Elfam Farm. International Journal of Innovative Research in Engineering \& Management, 2: 95-100.
[54] Jiang, Z. P., R. L. Yang, P. W. Guang, L. Qing, M. S. Tian, C. M. Yan, H. Y. Zhang and Y. L. Chang, 2012. Effect of longterm vinasse application on physico-chemical properties of sugarcane field soils. Sugar. Tech., 14: 412-417

[55] Tesfaye, W., Kibebew, K., Bobe, B., Melesse, T. and Teklu, E. 2019. Effects of Subsoiling and Organic Amendments on Selected Soil Physicochemical Properties and Sugar Yield in Metahara Sugar Estate. American- Eurasian Journal of Agricultural Research, 19: 312-325.

[56] Chamen, W. C.; Moxey, A. P.; Towers, W.; Balana, B.; Hallett, P. D. 2015. Mitigating arable soil compaction: A review and analysis of available cost and benefit data. Soil Tillage Res., 146: 10-25.

[57] Thomas, G. W., Haszler, G. R. and Blevins, R. L. 1996. The effect of organic matter and tillage on maximum compactibility of soils using the proctor test. Soil science, 161: 502-508.

[58] Meyer, J. H., Antwerpen, R. 2010. Advances in sugarcane soil fertility research in Southern Africa. South African Journal of Plant and Soil, 27: 19-31.

[59] Barzegar, A. R., Asoodar, M. A. and Ansari, M. 2000. Effectiveness of sugarcane residue incorporation at different water contents and the Proctor compaction loads in reducing soil compactibilty. Soil and Tillage Reseach, 57: 167-172.

[60] Usaborisut, P. and Niyamapa, T. 2010. Effects of machine induced soil compaction on growth and yield of sugarcane. America Journal of Agriculture and Biology Science, 3: 269273. 